\title{
Penggunaan Metode Pembelajaran Demonstrasi pada Mata Pelajaran Pendidikan Agama Islam dalam Upaya Meningkatkan Hasil Belajar Siswa Kelas V.A SD Negeri 114/X Pandan Jaya
}

\author{
Sutiban \\ SD Negeri 114/X Pandan Jaya \\ Jl. Hasanuddin, Pandan Jaya, Kec. Geragai, Kab. Tanjung Jabung Timur Prov. Jambi \\ sutiban658@gmail.com
}

\begin{abstract}
This study aims to disclose information and discuss the use of Demonstration Learning Methods in Islamic Religious Education Subjects in an Effort to Improve Student Learning Outcomes for Class V.A SD Negeri 114/X Pandan Jaya. This research is included in the type of classroom action research (CAR). This research was carried out in this research was carried out at SD Negeri 114/X Pandan Jaya. The time of this research was carried out in the odd semester of the academic year 2021 - 2022, which began in September 2021. The subjects in this study were class V.A students, totaling 25 people. The research procedure consisted of two cycles with four stages of research starting from planning, implementing, observing and reflecting. Data collection in this study was carried out using observation sheets, field notes, learning outcomes test sheets, and documents. The data were analyzed using the percentage formula. The results of this study indicate that through Demonstration Learning in Islamic Education Subjects can improve student learning outcomes in class VA SD Negeri 114/X Pandan Jaya which is marked by an increase from pre-cycle (20\%), cycle I (60\%), cycle II $(80 \%)$.
\end{abstract}

Keywords: Learning Outcomes, Islamic Religious Education Lessons, Demonstration Learning Methods

\begin{abstract}
Abstrak
Penelitian ini bertujuan untuk mengungkapkan informasi dan membahas tentang Penggunaan Metode Pembelajaran Demonstrasi pada Mata Pelajaran Pendidikan Agama Islam dalam Upaya Meningkatkan Hasil Belajar Siswa Kelas V.A SD Negeri 114/X Pandan Jaya. Penelitian ini termasuk dalam jenis penelitian tindakan kelas (PTK). Penelitian ini dilaksanakan di Penelitian ini dilaksanakan di SD Negeri 114/X Pandan Jaya. Waktu penelitian ini dilaksanakan pada semester ganjil tahun pelajaran 2021 - 2022, yang dimulai pada bulan September 2021. Subjek dalam penelitian ini adalah siswa kelas V.A yang berjumlah 25 orang. Prosedur penelitian terdiri dari dua siklus dengan empat tahap peneletian mulai dari perencanaan, pelaksanaan, observasi dan refleksi. Pengumpulan data dalam penelitian ini dilakukan dengan menggunakan lembar observasi, catatan lapangan, lembar tes hasil belajar, dan dokumen. Data dianalisis dengan menggunakan rumus persentase. Hasil penelitian ini menunjukkan bahwa melalui Pembelajaran Demonstrasi pada Mata Pelajaran Pendidikan Agama Islam dapat meningkatkan hasil belajar siswa di kelas V.A SD Negeri 114/X Pandan Jaya yang ditandai oleh meningkatnya dari pra siklus $(20 \%)$, siklus I (60\%), siklus II (80\%).
\end{abstract}

Kata Kunci : Hasil Belajar, Pelajaran Pendidikan Agama Islam, Metode Pembelajaran Demonstrasi

Corresponding author: Sutiban

Copyright (c) 2021 Sutiban

Email Address: sutiban658@gmail.com (Jl. Hasanuddin, Pandan Jaya, Kec. Geragai, Jambi)

Received 01 December, Accepted 13 December 2021, Published 28 December 2021

\section{PENDAHULUAN}

Pendidikan merupakan usaha sadar yang dengan sengaja dirancang untuk mencapai tujuan yang telah ditetapkan. Tujuan tersebut adalah untuk meningkatkan kualitas sumber daya manusia yang berdaya saing dalam percaturan global dewasa ini. Pemerintah telah berusaha untuk meningkatkan mutu pendidikan dengan berupaya kearah penyempurnaan kurikulum pendidikan KBK tahun 2004 menjadi KTSP tahun 2006 (Kurikulum Tingkat Satuan Pendidikan), menjadi Kurikulum 2013 (K13) dan sekarang menjadi KURNAS (Kurikulum Nasional). Pendidikan ialah suatu usaha 
yang dengan sengaja dipilih untuk mempengaruhi dan membantu anak yang bertujuan untuk meningkatkan ilmu pengetahuan, jasmani dan akhlak sehingga secara perlahan bisa mengantarkan anak kepada tujuan dan cita-citanya yang paling tinggi (Prof. H. Mahmud Yunus).

Hal ini telah dicantumkan dalam UU no.2 tahun 2003 tentang (SISDIKNAS) yaitu Pendidikan merupakan suatu usaha yang dilakukan secara sadar dan terencana untuk mewujudkan suasana dan proses pembelajaran agar peserta didik secara aktif mampu mengembangkan potensi yang ada didalam dirinya. Semua siswa harus belajar dengan rajin dan sungguh-sungguh, mempunyai kemauan yang kuat untuk belajar dan mau melakukannya adalah modal dasar siswa untuk sukses. Agar belajar lebih berhasil maka siswa mempunyai perhatian yang baik dalam belajar, menguasai materi pelajaran. Selain itu dalam kegiatan belajar mengajar, guru dituntut untuk kreatif dalam melaksanakan suatu metode pembelajaran tertentu agar seluruh siswa dapat belajar dengan aktif dalam mengembangkan segala kemampuannya baik kognitif, afektif, maupun psikomotor sehingga segala potensi yang dimiliki dapat dikembangkan secara optimal. Penggunaan variasi model pembelajaran yang tepat dapat menimbulkan suasana yang menyenangkan dalam kelas dan juga dapat meningkatkan hasil belajar siswa.

Menurut Permendiknas Nomor 211 Tahun 2011 dalam keputusan menteri, Pendidikan Agama Islam adalah pendidikan yang memberikan pengetahuan dan membentuk sikap, kepribadian, dan keterampilan peserta didik dalam mengamalkan Ajaran Agama Islam, yang dilakukan sekurangkurangnya melalui mata pelajaran pada semua jenjang pendidikan. Pendidikan agama ini sangat berfungsi untuk membentuk manusia Indonesia yang beriman dan bertaqwa kepada Tuhan Yang Maha Esa serta berakhlak mulia dan mampu menjaga perdamaian dan kerukunan hubungan inter atau antar umat beragama.

Peran guru bergeser dari menentukan "apa yang akan dipelajari" ke "bagaimana menyediakan dan memperkaya pengalaman belajar siswa". Pengalaman belajar diperoleh melalui serangkaian kegiatan untuk mengeksplorasi lingkungan melalui interaksi aktif dengan teman, lingkungan, dan nara sumber lain. Telah dilakukan upaya-upaya peningkatan hasil belajar mata pelajaran Pendidikan Agama Islam dengan cara peningkatan fasilitas-fasilitas penunjang pembelajaran, memberikan contoh-contoh yang nyata kepada siswa agar mereka lebih paham lagi, guru telah memberikan berbagai macam cara agar siswa tersebut paham dengan materi yang diajarkan oleh guru.

Bedasarkan observasi dan pengalaman mengajar peneliti di SD Negeri 114/X Pandan Jaya Kabupaten Tanjung Jabung Timur khususnya siswa kelas V.A Dalam proses pembelajaran siswa masih belum serius dalam melihat guru menerangkan pelajaran, dan siswa banyak bergurau dan bicara saat pembelajaran berlangsung. dengan jumlah siswa 25 orang dan KKM 75 namun nyata nya hanya beberapa siswa yang lulus KKM pada ulangan harian. Hal ini dapat dilihat hanya 5 siswa yang tuntas (20\%) dan selebihnya 20 siswa (80\%) belum tuntas belajar.

Salah satu upaya pemecahannya adalah dengan menggunakan metode pembelajaran demonstrasi. Dimana Metode Demonstrasi adalah pertunjukan tentang proses terjadinya suatu peristiwa atau benda 
sampai pada penampilan tingkah laku yang dicontohkan agar dapat diketahui dan dipahami oleh siswa secara nyata atau tiruannya (Syaiful, 2008:210).

Berdasarkan uraian diatas, penulis tertarik untuk mangadakan penelitian tindakan kelas (PTK). Dalam penelitian ini penulis memberi judul penelitian dengan: "Penggunaan Metode Pembelajaran Demonstrasi Pada Mata Pelajaran Pendidikan Agama Islam Dalam Upaya Meningkatkan Hasil Belajar Siswa Kelas V.A SD Negeri 114/X Pandan Jaya”.

Menurut Trianto (2012:17) Belajar adalah sebagai proses perubahan perilaku tetap dari belum tahu menjadi tahu, dari tidak paham menjadi paham, dari kurang terampil menjadi terampil, dan dari kebiasaan lama menjadi kebiasaan baru, serta bermanfaat bagi lingkungan maupun individu itu sendiri. Menurut Slameto (2010:2) Belajar ialah suatu proses usaha yang dilakukan seseorang untuk memperoleh suatu perubahan tingkah laku yang baru secara keseluruhan, sebagai hasil pengalamannya sendiri dalam interaksi dengan lingkunganya.

Menurut Pribady (2011:6) Belajar adalah kegiatan yang dilakukan oleh seseorang agar memiliki kompetensi berupa keterampilan dan pengetahuan yang di perlukan. Belajar juga dapat dipandang sebagai sebuah proses elaborasi dalam upaya pencarian makna yang dilakukan oleh individu. Proses belajar pada dasarnya di lakukan untuk meningkatkan kemampuan atau kompetensi personal. Menurut Suprijono (2012:3) Belajar sebagi konsep mendapatkan pengetahuan dalam praktiknya banyak dianut. Guru bertindak sebagai pengajar yang berusaha memberikan ilmu pengetahuan sebanyak-banyaknya dan peserta didik giat mengumpulkan atau menerimanya. Menurut Suryono dkk (2012:9) Belajar adalah suatu aktivitas atau memperoleh, pengetahuan, meningkatkan keterampilan, memperbaiki perilaku, sikap dan mengokohkan kepribadian.

Dari uraian di atas dapat disimpulkan bahwa belajar merupakan suatu proses yang terjadi dalam diri seseorang baik secara internal maupun eksternal yang dapat merubah pola prilaku maupun tingkah laku seseorang. Menurut pemikiran Gagne dalam Agus Suprijono (2012:5-6) Hasil belajar berupa informasi verbal, keterampilan intelektual, strategi kognitif, keterampilan motorik, sikap. Menurut Bloom dalam Agus Suprijono (2012:6) Hasil belajar mencakup kemampuan kognitif, afektif, dan psikomotor. Menurut Suprijono (2012:5) Hasil belajar adalah pola-pola perbuatan, nilai-nilai, pengertian-pengertian, sikap-sikap, dan apresiasi dan keterampilan.

Menurut Uno (2011:21) Hasil belajar adalah variable metode dan kondisi pembelajaran, variable hasil pembelajaran juga dapat diklasifikasikan dengan cara yang sama, pada tingkat yang amat umum sekali hasil pembelajaran dapat diklasifikasikan menjadi 3 (tiga) yaitu keefektifan, efesisensi, daya tarik.

Dari uraian diatas dapat disimpulkan hasil belajar adalah perubahan perilaku secara keseluruhan berupa kemampuan kognitif, afektif, keterampilan, daya tarik, apresiasi dan informasiinformasi verbal.

Pendidikan Agama Islam diberikan dengan tuntunan bahwa agama diajarkan kepada manusia dengan visi untuk mewujudkan manusia yang bertaqwa kepada Allah SWT dan berakhlaq mulia, serta 
bertujuan untuk menghasilkan manusia yang jujur, adil, berbudi, pekerti, etnis, saling menghargai, disiplin, harmonis, dan produktif.

Adapun ruang lingkup Pendidikan Agama Islam meliputi aspek-aspek sebagai berikut : ALQuran dan Hadist, Aqidah akhlak, fiqih, tarikh dan kebudayaan islam. Pendidikan Agama Islam menekankan keseimbangan, keselarasan, keserasian, antara hubungan manusia dengan Allah SWT, hubungan manusia dengan sesama manusia, hubungan manusia dengan diri sendiri, danhubungan manusia dengan alam sekitarnya.

Pendidikan Agama Islam adalah pendidikan yang memberikan pengetahuan dan membentuk sikap, kepribadian, dan keterampilan peserta didik dalam mengamalkan ajaran Agama Islam, yang dilaksanakan sekurang-kurangnya melalui mata pelajaran pada semua jenjang pendidikan.

Trianto (2012:51) metode pembelajaran adalah suatu perancanaa atau suatu pola yng digunakan sebagai pedoman dalam merencanakan dikelas atau pebelajaran tutorial. Arends (1997) dalam trianto (2009:22), metode pembelajaran adalah the term teaching model refers to a particular approach to instruction that include its goals, syntax, environment, and management system.

Rusman (2012:133), metode pembelajaran adalah suatu rencana atau pola yang dapat digunakan untuk membentuk kurikulum (rencana pembelajaran jangka panjang), merancang bahanbahan pembelajaran dan membimbing pembelajaran dikelas yang lain. Agus Suprijono (2010:46) metode pembelajaran ialah pola yang digunakan sebagai pedoman dalam merencanakan pembelajaran dikelas maupun tutorial.

Dari uraian di atas dapat disimpulkan bahwa metode pembelajaran adalah suatu rencana mengajar yang digunakan sebagai pedoman dalam pembelajaran di kelas maupun tutorial.

Metode Demonstrasi adalah pertunjukan tentang proses terjadinya suatu peristiwa atau benda sampai pada penampilan tingkah laku yang dicontohkan agar dapat diketahui dan dipahami oleh siswa secara nyata atau tiruannya (Syaiful, 2008:210). Metode Demonstrasi adalah metode mengajar dengan cara memperagakan barang, kejadian, aturan, dan urutan melakukan suatu kegiatan, baik secara langsung maupun melalui penggunaan media pengajaran yang relevan dengan pokok bahasan atau materi yang sedang disajikan (Muhibbin Syah, 2000:22).

Sementara menurut Syaiful Bahri Djamarah, (2000:2) bahwa metode demonstrasi adalah metode yang digunakan untuk memperlihatkan sesuatu proses atau cara kerja suatu benda yang berkenaan dengan bahan pelajaran. Menurut Syaiful (2008:210) metode Demonstrasi ini lebih sesuai untuk mengajarkan bahan-bahan pelajaran yang merupakan suatu gerakan-gerakan, suatu proses maupun hal-hal yang bersifat rutin.

\section{METODE}

Penelitian ini termasuk dalam jenis penelitian tindakan kelas (PTK). Penelitian ini dilaksanakan di Penelitian ini dilaksanakan di SD Negeri 114/X Pandan Jaya. Waktu penelitian ini dilaksanakan pada semester ganjil tahun pelajaran 2021 - 2022, yang dimulai pada bulan September 
2021. Subjek dalam penelitian ini adalah siswa kelas V.A yang berjumlah 25 orang. Prosedur penelitian terdiri dari dua siklus dengan empat tahap peneletian mulai dari perencanaan, pelaksanaan, observasi dan refleksi. Pengumpulan data dalam penelitian ini dilakukan dengan menggunakan lembar observasi, catatan lapangan, lembar tes hasil belajar, dan dokumen. Data dianalisis dengan menggunakan rumus persentase.

\section{HASIL DAN DISKUSI}

\section{Paparan Pra Siklus}

Kegiatan pengambilan data pra siklus dilakukan di kelas V.A dengan jumlah siswa 25 orang. Pra siklus dilakukan peneliti dengan cara melaksanakan kegiatan pembelajaran Pendidikan Agama Islam dengan menggunakan metode tanya jawab atau pembelajaran banyak didominasi oleh guru yang diakhiri dengan pelaksanaan tes.

Hasil proses pembelajaran terlihat monoton dan berpusat pada guru, tingkat partisipasi siswa dalam belajar rendah, kurang termotivasi dalam belajar, banyak siswa yang tidak memperhatikan ketika guru menerangkan pelajaran di depan kelas, dan mengobrol bersama temannya, serta kurang paham nya siswa saat melakukan tugas yang diberikan oleh guru, sehingga membuat nilai atau hasil belajarnya rendah. Untuk lebih jelasnya dapat dilihat pada tabel di bawah ini:

Tabel 1. Rekapitulasi Hasil Belajar Siswa Pra Siklus

\begin{tabular}{|l|c|}
\hline Jumlah Nilai & $\mathbf{1 7 9 6}$ \\
\hline Rata - Rata & $\mathbf{7 1 , 8 4}$ \\
\hline KKM & $\mathbf{7 5}$ \\
\hline Jumlah Siswa Yang Tuntas & 5 Orang / 20\% \\
\hline Jumlah Siswa Yang Belum Tuntas & $\mathbf{2 0}$ Orang / 75\% \\
\hline
\end{tabular}

Dari tabel di atas dapat dijelaskan bahwa sebelum menerapkan metode pembelajaran demonstrasi di peroleh rata - rata hasil belajar siswa yaitu 71,84 dengan persentase ketuntasan 20\% atau 5 orang dari 25 siswa yang tuntas belajar. Hasil tersebut menunjukkan bahwa pada pra siklus secara klasikal siswa belum tuntas belajar, karena hanya 5 siswa yang memperoleh nilai $\geq 75$ atau hanya sebesar 25\% yang mencapai kriteria ketuntasan minimum (KKM).

Sehingga, masih terdapat 20 dari 25 orang yang belum tuntas belajar atau sebanyak $80 \%$. Hasil tersebut lebih kecil dari presentase ketuntasan klasikal dalam proses pembelajaran Pendidikan Agama Islam yang dikehendaki sebesar $80 \%$ siswa yang tuntas. Berdasarkan tabel nilai dan penjelasan nilai pra siklus diatas dapat dilihat lebih jelas pada diagram dibawah ini: 


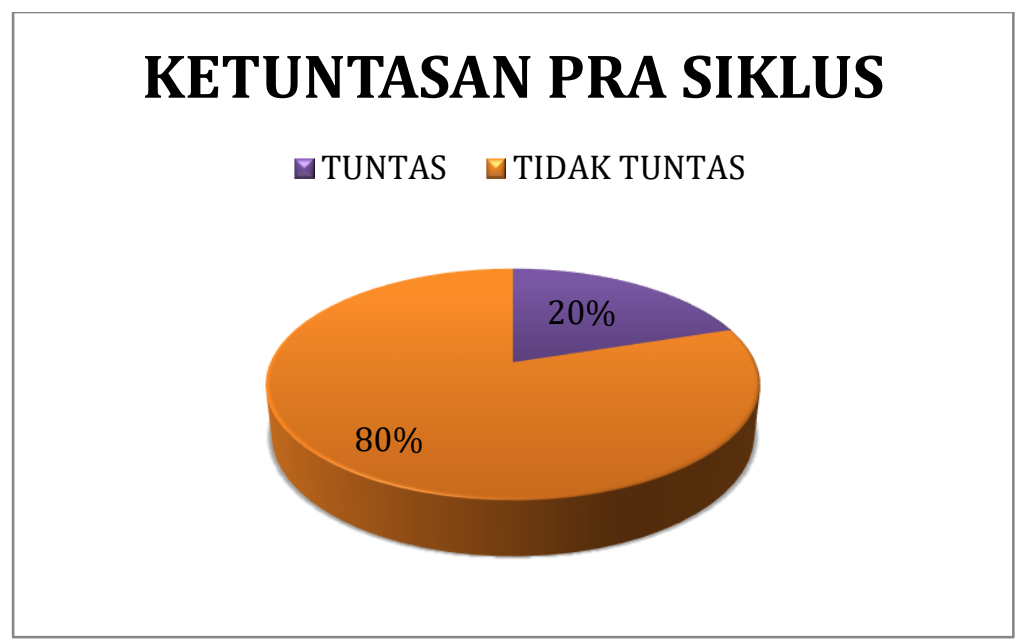

Gambar 1. Ketuntasan Hasil Belajar Siswa Pra Siklus

\section{Hasil Penelitian}

\section{Siklus I}

\section{Tahap Perencanaan}

Sebelum melakukan pengumpulan data berupa kegiatan pembelajaran, peneliti terlebih dahulu menyusun perencanaan kegiatan yang meliputi:

a. Mempersiapkan jadwal penelitian tindakan kelas.

b. Merencanakan materi yang akan dilaksanakan pada waktu penelitian agar mengetahui kompetensi dasar yang akan disampaikan kepada siswa dalam pembelajaran.

c. Mempersiapkan RPP.

d. Mempersiapkan silabus, LKS, instrumen.

e. Mempersiapkan media pembelajaran yang dibutuhkan.

f. Mempersiapkan alat demonstrasi.

\section{Tahap Pelaksanaan}

Pelaksanaan kegiatan belajar mengajar untuk siklus I pertemuan pertama dilaksanakan pada hari selasa tanggal 3 Agustus 2021 dan pertemuan kedua dilaksanakan pada hari Jumat tanggal 6 Agustus 2021 di kelas V dengan jumlah siswa 25 orang. Dalam hal ini peneliti bertindak sebagai guru. Adapun proses belajar mengajar mengacu pada rencana pelaksanaan pembelajaran yang telah dipersiapkan sesuai dengan rancangan metode pembelajaran Demonstrasi.

\section{Observasi}

Pengamatan (observasi) dilaksanakan bersamaan dengan pelaksaaan belajar mengajar yang dilakukan oleh observer. Adapun yang diamati oleh Observer meliputi pengelolaan belajar mengajar guru, aktivitas guru dan aktivitas siswa selama proses pembelajaran. Pada akhir proses belajar mengajar siswa diberi tes formatif dengan tujuan untuk mengetahui tingkat keberhasilan siswa dalam proses belajar mengajar yang telah dilakukan. Adapun data hasil penelitian pada siklus I adalah sebagai berikut: 
Tabel 2. Rekapitulasi Hasil Belajar Siswa Siklus I

\begin{tabular}{|l|c|}
\hline Jumlah Nilai & 1900 \\
\hline Rata -Rata & 76 \\
\hline KKM & 75 \\
\hline Jumlah Siswa Yang Tuntas & 15 Orang / 60\% \\
\hline Jumlah Siswa Yang Belum Tuntas & 10 Orang / 45\% \\
\hline
\end{tabular}

Dari tabel di atas dapat dijelaskan bahwa dengan menerapkan pembelajaran dengan metode pembelajaran demonstrasi, diperoleh rata-rata hasil belajar siswa adalah 76 dengan jumlah siswa yang tuntas sebanyak 15 orang dengan persentase $60 \%$ dan siswa yang tidak tuntas sebanyak 10 orang dengan persentase $40 \%$. Selanjutnya Hasil tersebut menunjukkan bahwa pada siklus pertama secara klasikal siswa belum tuntas belajar, karena siswa yang memperoleh nilai $\geq 75$ hanya sebesar $60 \%$ lebih kecil dari persentase ketuntasan yang dikehendaki yaitu sebesar $80 \%$. Hal ini disebabkan karena siswa masih belum bisa menyesuaikan diri dengan pokok bahasan materi yang disampaikan melalui metode pembelajaran demonstrasi, tersebut. Untuk lebih jelasnya mengenai hasil belajar siswa pada sikluls I ini dapat dilihat gambar diagram ketuntasan belajar dibawah ini:

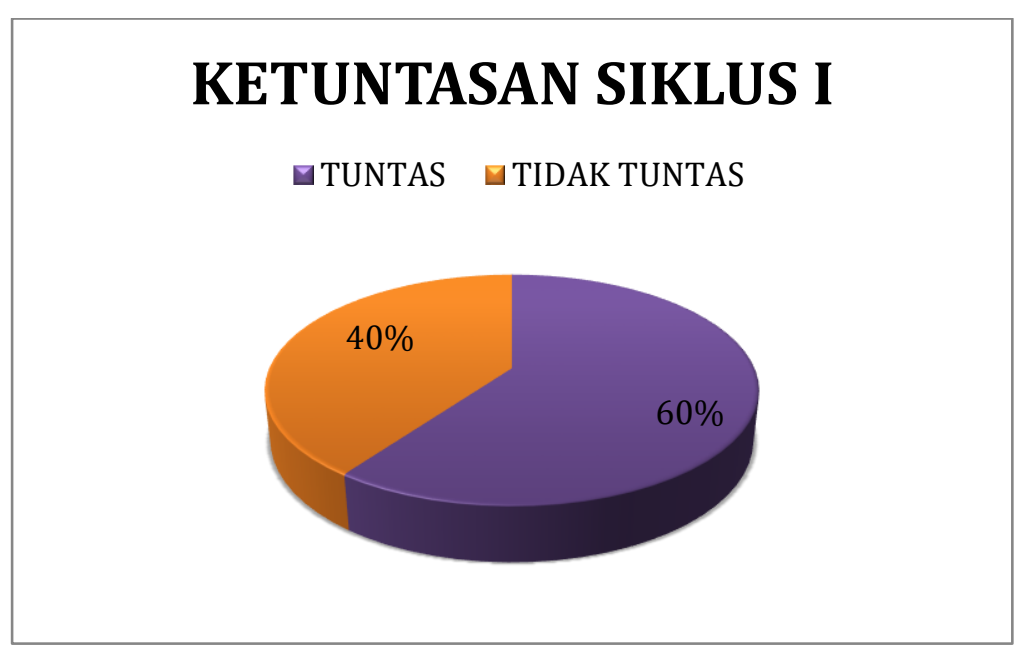

Gambar 2. Ketuntasan Hasil Belajar Siswa Siklus I

\section{Refleksi}

Berdasarkan hasil pengamatan observer (Deby Utoyo,S.Pd) serta diskusi yang di lakukan di ruang majelis guru terhadap kegiatan belajar mengajar yang dilakukan oleh peneliti pada siklus I, dapat disimpulkan:

a. Memotivasi siswa masih lemah.

b. Kurang terkontrol dalam mengawasi setiap siswa secara bergiliran

c. Kurang baik dalam memberikan evaluasi

d. Kurang baik dalam pengelolaan waktu.

e. Siswa kurang antusias dalam belajar

Berdasarkan temuan pada siklus I diatas, maka untuk mengantisispasi supaya tidak terjadi pada pertemuan berikutnya, maka perlu dilakukan evaluasi dengan merencanakan: 
a. Memberikan motivasi yang kuat terhadap siswa

b. Memberikan evaluasi yang baik lagi

c. Mengelola waktu dengan baik dan

d. Menyiapkan rewort untuk yang memiliki antusias serta nilai yang tinggi.

\section{Siklus II}

\section{Tahap Perencanaan}

Tahap perencanaan dalam siklus II ini adalah menyusun RPP, menyusun lembar pengamatan, menyiapkan media pendukung pembelajaran, membuat instrumen beserta jawaban, menyiapkan alat demonstrasi dan menyiapkan LKS.

\section{Tahap Pelaksanaan}

Penelitian pada siklus II dilaksanakan selama 2 kali pertemuan, pertemuan dilaksanakan pada hari jumat tanggal 13 Agustus 2021 dan Pertemuan II dilaksanakan pada hari Jumat tanggal 20 Agustus 2021. Dalam penelitian ini, peneliti akan dibantu 1 orang teman sejawat yang akan bertindak sebagai pengamat (Observer).

\section{Observasi}

Kegiatan Pengamatan atau Observasi dilaksanakan bersamaan dengan pelaksanaan belajar mengajar. Kegiatan Observasi oleh Observer dilakukan selama peneliti melaksanakan kegiatan proses belajar mengajar. Adapun yang diamati oleh observer meliputi pengelolaan belajar mengajar guru, aktivitas guru dan aktivitas siswa selama proses pembelajaran.

Selain itu, pada setiap akhir proses belajar mengajar siswa akan diberikan tes, dengan tujuan untuk mengukur sejauh mana tingkat keberhasilan peneliti dalam melaksanakan proses pembelajaran. Berikut hasil tes siswa pada siklus II dapat dilihat jelas pada tabel berikut:

Tabel 3. Rekapitulasi Hasil Belajar Siswa Siklus II

\begin{tabular}{|l|c|}
\hline Jumlah Nilai & 2018 \\
\hline Rata - Rata & $\mathbf{8 0 , 7 2}$ \\
\hline KKM & 75 \\
\hline Jumlah Siswa Yang Tuntas & $\mathbf{2 2}$ Orang / 88\% \\
\hline Jumlah Siswa Yang Belum Tuntas & $\mathbf{3}$ Orang / 12\% \\
\hline
\end{tabular}

Dari tabel siklus II diatas, terlihat bahwa hasil belajar siswa mengalami peningkatan yang lebih baik dari siklus I. Hasil rata-rata nilai yang diperoleh siswa pada siklus II ini sebesar 80,72 yakni dari 25 siswa sebanyak 22 orang pada siklus II ini sudah berhasil mendapat nilai yang baik yakni $\geq 75$ dengan ketuntasan belajar mencapai 88\% Hal ini menunjukkan bahwa pada siklus II secara klasikal siswa telah tuntas belajar, karena siswa yang memperoleh nilai $\geq 75$ telah meningkat sebanyak $88 \%$ lebih besar dari persentase ketuntasan yang dikehendaki yaitu sebesar $80 \%$.

Dari data tersebut dapat disimpulkan bahwa adanya peningkatan hasil belajar pada siklus II ini dapat terjadi karena guru selalu menginformasikan bahwa setiap akhir pelajaran akan selalu diadakan tes sehingga pada pertemuan berikutnya siswa lebih siap dan termotivasi untuk belajar. Selain itu juga terjadi peningkatan kemampuan guru dalam menerapkan metode pembelajaran 
Demonstrasi, sehingga membuat siswa menjadi lebih terbiasa dengan pembelajaran menggunakan metode Pembelajaran Demonstrasi, Hal ini akan berpengaruh baik terhadap peningkatan hasil belajar. Untuk lebih jelasnya dapat dilihat tabel ketuntasan hasil belajar dibawah ini:

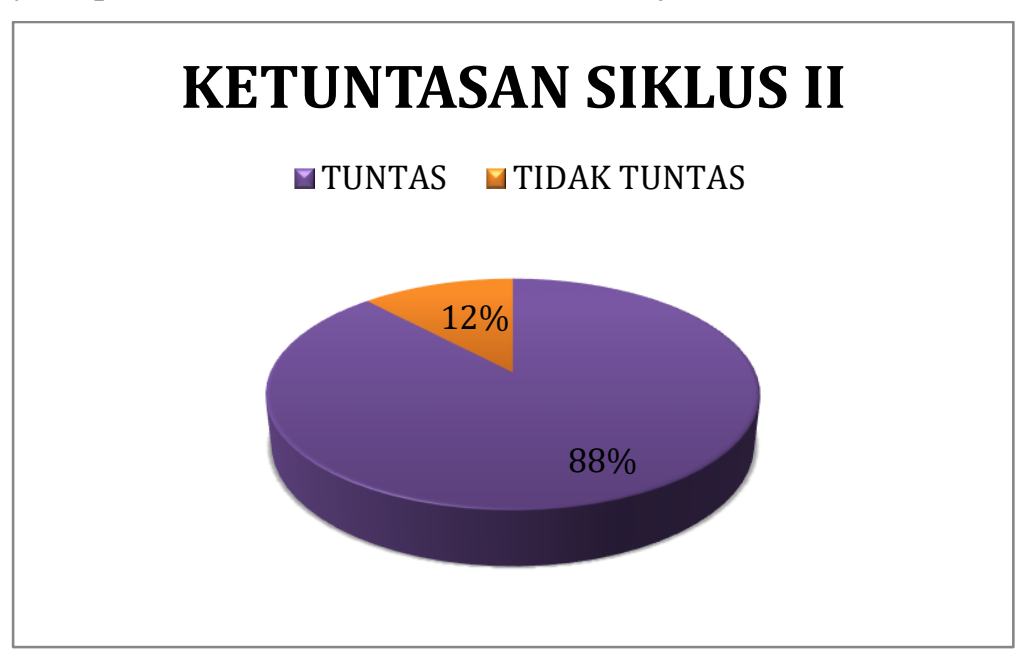

Gambar 3. Ketuntasan Hasil Belajar Siswa Siklus II

\section{Refleksi}

Pada tahap ini akan dikaji apa yang telah terlaksana dengan baik maupun yang masih kurang baik dalam proses belajar mengajar dengan penerapan belajar aktif. Berdasarkan hasil diskusi yang telah dilakukan dengan observer (Deby Hutoyo,S.Pd) diruang majelis guru. Dari data-data yang telah diperoleh selama proses pembelajaran menggunakan metode pembelajaran demonstrasi, dapat diuraikan sebagai berikut:

a. Selama proses belajar mengajar guru telah melaksanakan semua pembelajaran dengan baik. Meskipun ada beberapa aspek yang belum sempurna, tetapi persentase peningkatan pelaksanaannya untuk masing-masing aspek cukup besar.

b. Berdasarkan data hasil pengamatan diketahui bahwa dalam setiap pertemuan, siswa semakin meningkat keaktifannya selama proses belajar berlangsung.

c. Kekurangan pada siklus-siklus sebelumnya sudah mengalami perbaikan dan peningkatan sehingga menjadi lebih baik.

d. Hasil belajar siswa pada siklus II telah berhasil mencapai ketuntasan.

\section{Pembahasan}

Melalui hasil penelitian ini, menunjukkan bahwa pembelajaran dengan metode pembelajaran Demonstrasi, memiliki dampak positif dalam meningkatkan hasil belajar siswa. Hal ini dapat dilihat dari semakin mantapnya pemahaman dan penguasaan siswa terhadap materi yang telah disampaikan guru pada setiap pelaksanaan siklus. Ketuntasan belajar meningkat mulai dari pra siklus, siklus I, dan siklus II yaitu masing-masing 20\%, 60\% dan 88\%. Pada siklus II ketuntasan belajar siswa secara klasikal telah tercapai dan mengalami peningkatan yang sangat baik. 
Penggunaan Metode Pembelajaran Demonstrasi pada Mata Pelajaran Pendidikan Agama Islam dalam Upaya Meningkatkan Hasil Belajar Siswa Kelas V.A SD Negeri 114/X Pandan Jaya, Sutiban

Metode Demonstrasi adalah pertunjukan tentang proses terjadinya suatu peristiwa atau benda sampai pada penampilan tingkah laku yang dicontohkan agar dapat diketahui dan dipahami oleh siswa secara nyata atau tiruannya (Syaiful, 2008:210). Metode Demonstrasi adalah metode mengajar dengan cara memperagakan barang, kejadian, aturan, dan urutan melakukan suatu kegiatan, baik secara langsung maupun melalui penggunaan media pengajaran yang relevan dengan pokok bahasan atau materi yang sedang disajikan (Muhibbin Syah, 2000:22). Untuk lebih jelasnya dapat dilihat gambar dibawah ini:

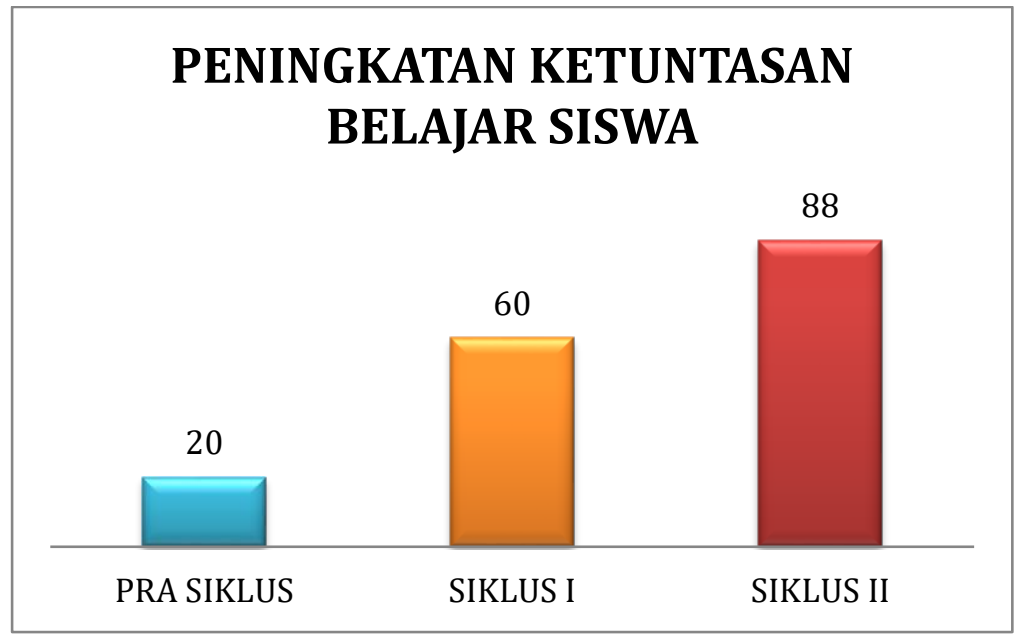

Gambar 4. Peningkatan Ketuntasan Belajar Siswa

\section{KESIMPULAN}

Dari hasil kegiatan pembelajaran yang telah dilakukan selama dua siklus, dan berdasarkan seluruh pembahasan serta analisis yang telah dilakukan dapat disimpulkan sebagai berikut:

1. Pembelajaran dengan menggunakan metode demonstrasi, memiliki dampak positif dalam meningkatkan hasil belajar siswa yang ditandai dengan peningkatan ketuntasan belajar siswa dalam setiap siklus, yaitu pra siklus (20\%), siklus I (60\%), siklus II (88\%).

2. Penerapan metode pembelajaran demonstrasi, mempunyai pengaruh positif, yaitu dapat meningkatkan hasil belajar siswa yang ditunjukan dengan rata-rata jawaban siswa yang menyatakan bahwa siswa tertarik dan berminat dengan metode pembelajaran demonstrasi, sehingga mereka menjadi termotivasi untuk belajar.

Dari hasil penelitian yang diperoleh dari uraian sebelumnya agar proses belajar pembelajaran Pendidikan Agama Islam lebih efektif dan lebih memberikan hasil yang optimal bagi siswa, maka disampaikan saran sebagai berikut:

1. Untuk melaksanakan metode pembelajaran demonstrasi, memerlukan persiapan yang cukup matang, sehingga guru harus mempu menentukan atau memilih topik yang benar-benar bisa diterapkan dengan metode pembelajaran demonstrasi, dalam proses belajar mengajar sehingga diperoleh hasil yang optimal. 
2. Dalam rangka meningkatkan hasil belajar siswa, guru hendaknya lebih sering melatih siswa dengan berbagai metode pengajaran, walau dalam taraf yang sederhana, dimana siswa nantinya dapat menemukan pengetahuan baru, memperoleh konsep dan keterampilan, sehingga siswa

3. berhasil atau mampu memecahkan masalah-masalah yang dihadapinya.

4. Perlu adanya penelitian yang lebih lanjut, karena hasil penelitian ini hanya dilakukan di SD Negeri 114/X Pandan Jaya semester I tahun pelajaran 2021/2022.

5. Untuk penelitian yang serupa hendaknya dilakukan perbaikan-perbaikan agar diperoleh hasil yang lebih baik.

\section{REFERENSI}

Agus suprijono. 2010. Cooperative Learning. Yogyakarta. Pustaka Media.

Agus, Suprijono. 2012. Cooperative Learning: Teori dan Aplikasi Paikem. Yogyakarta: Pustaka Pelajar.

Arikunto. 2005. Metode Penelitian Kualitatif. Jakarta: Sagung Seto

Bahri Djamarah, Syaiful. 2008. Psikologi Belajar. (Jakarta: PT. Rineka Cipta).

Muhibbin, Syah. 2000. Psikologi Pendidikan Dengan Pendekatan Baru. Bandung: Remaja Rosdakarya.

Paidi. (2008). Peningkatan Scientific Skill Siswa Melalui Implementasi Metode Guided Inquiry pada Pembelajaran Biologi. Yogyakarta : Universitas Negeri Yogyakarta.

Pribadi, Benny A. 2011. Model Desain Assure untuk Mendesain Pembelajaran Sukses. Jakarta: Dian Rakyat.

Rusman, 2012. Model-model Pembelajaran: Mengembangkan Profesionalisme Guru, RajaGrafindo Persada, Jakarta.

Sanjaya, W. 2006. Strategi Pembelajaran. Jakarta: Kencana Prenada Media Group.

Slameto. (2003). Belajar dan Faktor-faktor yang mempengaruhinya. Jakarta: Rineka Cipta.

Slameto. 2010. Belajar dan faktor-faktor yang Mempengaruhinya. Jakarta: PT. Rineka Cipta

Suryono dan Hariyanto. (2012). Belajar dan Pembelajaran. Bandung: Remaja Rosdakarya.

Trianto. 2010. Model Pembelajaran Terpadu, Konsep, Strategi dan Implementasinya dalam KTSP. Jakarta: Bumi Aksara.

Trianto. 2012. Model Pembelajaran Terpadu. (Jakarta: PT Bumi Aksara).

UU no. 2 tahun 2003 tentang (SISDIKNAS)

Uno B. Hamzah, 2011. Teori Motivasi dan Pengukurannya Analisis di Bidang Pendidikan, Jakarta: PT. Bumi Aksara

Permendiknas Nomor 211 Tahun 2011 